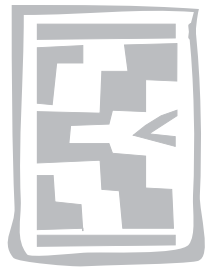

\title{
The detection of lumpy skin disease virus in samples of experimentally infected cattle using different diagnostic techniques
}

\author{
E.S.M. TUPPURAINEN, E.H. VENTER* and J.A.W. COETZER \\ Department of Veterinary Tropical Diseases, Faculty of Veterinary Science, University of Pretoria \\ Private Bag X04, Onderstepoort, 0110 South Africa
}

\begin{abstract}
TUPPURAINEN, E.S.M., VENTER, E.H. \& COETZER, J.A.W. 2005. The detection of lumpy skin disease virus in samples of experimentally infected cattle using different diagnostic techniques. Onderstepoort Journal of Veterinary Research, 72:153-164

Lumpy skin disease (LSD) is a disease of cattle, primarily in Africa and Madagascar and rarely in the Middle East. It is caused by a capripoxvirus that belongs to the family Poxviridae. The disease is of economic importance in endemic areas. Effective control of LSD requires accurate and rapid laboratory techniques to confirm a tentative clinical diagnosis. Comparative studies on different diagnostic tests used at different stages of the disease have not been done. The aim of this study was to compare several of these tests.

Six seronegative bulls, between 11 and 20 months of age, were infected intravenously and kept in an insect-free facility. The course of the infection was monitored. During a 3-month period blood samples and skin biopsies were collected for virus isolation and polymerase chain reaction (PCR). Skin biopsies were also examined using transmission electron microscopy (TEM).

The incubation period in infected animals varied from 4-5 days. The length of the viraemic period did not correlate with the severity of clinical disease. Viraemia was detected from 1-12 days using virus isolation and from 4-11 days using the PCR, which is longer than has previously been reported. Virus was isolated from skin biopsies until Day 39 post infection (p.i.) and PCR could demonstrate viral DNA until Day 92 p.i. Transmission electron microscopy of negatively stained skin biopsies detected LSD virus only in one of the four bulls that developed skin lesions until Day 33 p.i.

The PCR was a fast and sensitive method to demonstrate viral DNA in blood and skin samples. It could detect viral nucleic acid in skin lesions 53 days longer than virus isolation. Virus isolation from blood and skin samples was sensitive and reliable, but as a single test it may be too time-consuming to use although this depends on how rapidly the diagnosis must be confirmed.

In conclusion, this study showed the PCR to be superior in detecting LSD virus from blood and skin samples. However, virus isolation is still required when the infectivity of the LSD virus is to be determined.
\end{abstract}

Keywords: Lumpy skin disease, polymerase chain reaction, virus isolation

\section{INTRODUCTION}

Lumpy skin disease (LSD) in cattle is caused by a capripoxvirus. It is characterized by fever, enlarged

* Author to whom correspondence is to be directed. E-mail: Estelle.venter@up.ac.za

Accepted for publication 6 April 2005-Editor lymph nodes, firm, circumscribed nodules in the skin and ulcerative lesions particularly of the mucous membrane of the mouth. It usually occurs at regular intervals in endemic areas or it may cause epidemics, which spread fairly rapidly throughout a region or country (Davies 1991).

Field and experimental evidence have proved that LSD is not highly contagious. The morbidity rates in 
natural outbreaks vary from 3-85\%. In experimentally produced infections only $40-50 \%$ of inoculated animals have shown clinical signs. The mortality rate is usually low and less than $10 \%$ (Thomas \& Maré 1945).

A presumptive diagnosis of the disease can be made based on clinical signs. However, mild and inapparent disease may be difficult to diagnose and rapid laboratory methods are needed to confirm the diagnosis.

Laboratory diagnosis of LSD can be performed either by identification of the agent using transmission electron microscopy (TEM), by its isolation in cell cultures, by a direct fluorescent antibody test (FAT) or by detection of antibody using conventional serological tests such as the serum virus neutralization test (SNT), indirect fluorescent antibody test (IFAT) and agar-gel immunodiffusion test (AGID). Routine histopathology and immunohistological staining provide a relatively inexpensive tool to diagnose the disease. Indirect and antigen trapping ELISAs as well as the polymerase chain reaction (PCR) have been developed more recently for detecting LSD antibodies and antigen (Carn, Kitching, Hammond \& Chand 1994; Carn 1995; Ireland \& Binepal 1998; Heine, Stevens, Foord \& Boyle 1999).

The disease is of economic importance because of decreased milk yield and mass loss, infertility and permanent damage to hides. It is endemic in most parts of sub-Saharan Africa and Madagascar and rarely causes outbreaks in the Middle East (OIE's computer data page, Handistatus II, Multiannual animal disease status).

Vaccination is the only effective method to control the disease in endemic countries. In previously LSD-free countries, in the event of an outbreak, the rapid confirmation of a clinical diagnosis is essential so that eradication measures, such as quarantine, slaughter-out of affected and in-contact animals, and ring vaccinations can be implemented as soon as possible (Carn 1993).

The aim of this study was to monitor the clinical signs of bulls experimentally infected with LSD virus and to determine virus persistence in blood and skin lesions using virus isolation, PCR and TEM.

\section{MATERIALS AND METHODS}

\section{Experimental animals}

Six bulls, between 11 and 20 months of age, from a herd where vaccination against LSD was not prac- tised were used as experimental animals. They were thin-skinned, European breeds: two HolsteinFriesians, two Dexters and two Dexter crosses (Table 1). Before they were purchased and again before the onset of the experiment the animals were tested to be seronegative using the SNT. During the experiment the animals were kept in isolation in the insect proof facility of the University of Pretoria's Biomedical Research Centre. Before the onset of the experiment the bulls had a period of 2 weeks to acclimatize to the new environment. The experimental animals were numbered with ear tags (1-4 and 7-8).

\section{Preparation of virus suspension and animal inoculation}

A virulent, South African field isolate strain V248/93 of LSD virus that had been passaged three times in cell cultures was used to infect the animals.

Bovine dermis cells prepared from a foetal calf's ears were cultured in $75 \mathrm{~cm}^{2}$ tissue culture flasks in a growth medium comprising Minimum Essential Medium (MEM) with L-glutamine (Highveld Biological), $0.2 \%$ sodium bicarbonate (Highveld Biological), $5 \%$ foetal calf serum (Adcock Ingram) and gentamycin 0,05 mg/m $\ell$ (Genta 50 Phenix, $50 \mathrm{mg} / \mathrm{m} \ell$ ).

Two hours after preparation of the cells $0.5 \mathrm{~m} \ell$ of the virus suspension was inoculated into the $75 \mathrm{~cm}^{2}$ flasks containing bovine dermis cells in the growth medium. Virus was harvested when $90-100 \%$ of the cells in the monolayer were infected and showed the typical cytopathic effect (CPE) caused by LSD virus. Culture flasks were briefly frozen at $-70^{\circ} \mathrm{C}$ and then thawed. The cell suspension was centrifuged for 3 min at $2000 \mathrm{rpm}$, the supernatant removed and aliquoted in $1.8 \mathrm{~m} \ell$ or $3.5 \mathrm{~m} \ell$ volumes in cryotubes and stored as reference stock virus at $-70^{\circ} \mathrm{C}$ until used.

The reference stock virus was titrated on bovine dermis cells growing in the wells of 96-well microtitre plates containing the growth medium, and the tissue culture infected dose $50\left(\mathrm{TCID}_{50}\right)$ of the virus was calculated using the method of Reed \& Muench (1938).

The bulls were inoculated intravenously (IV) with $2 \mathrm{~m} \ell$ of the virus suspension at a titre of $5 \log \mathrm{TCID}_{50}$.

\section{Clinical observations, sample collection and processing}

After infection the bulls were clinically examined daily and their rectal temperatures were measured twice a day for 30 days p.i. Blood and affected skin 
biopsy samples were collected at various intervals.

After inoculation blood samples in EDTA and in heparin were collected daily for 30 days p.i. and then at 3-day intervals up to Day 40. After collection of the blood samples they were aliquoted in $1.8 \mathrm{~m} \ell$ volumes in cryotubes. The heparinized blood was stored at $-70^{\circ} \mathrm{C}$ and the EDTA blood at $-20^{\circ} \mathrm{C}$.

Biopsies of the nodular skin lesions comprising epidermis, dermis and subcutis were collected for virus isolation, PCR and TEM. Samples were collected at weekly intervals for more than 3 months. The skin area was anaesthetized locally using $2 \%$ Lignocaine ${ }^{\circledR}$ (Lignocaine HCL, Bayer $\mathrm{AH}$ ) before the biopsies were taken. Those animals showing signs of discomfort during the procedure were tranquillized by administration of Domosedan $\AA$ (detomidine, Novartis/Orion Pharma) sedative. Standard sterile techniques were used to take the samples and the resultant skin wounds were sutured with 2-0 Ethicon Vicryl (Johnson \& Johnson Intl). Samples were divided into three pieces, which were placed in 1.8 $\mathrm{m} \ell$ cryotubes. These were stored either at $-20^{\circ} \mathrm{C}$ for PCR or at $-70^{\circ} \mathrm{C}$ for virus isolation. On the day of collection of the skin nodules, samples were submitted to the Electron Microscopy Unit, Department of Anatomy and Physiology, Faculty of Veterinary Science, University of Pretoria.

The presence of virus was determined in the samples using the PCR, virus isolation and TEM using several standard operating procedures (SOPs) of the Department of Veterinary Tropical Diseases and Electron Microscopy Unit or using other published procedures as described below.

\section{Diagnostic methods}

\section{Virus isolation}

\section{HEPARANIZED BLOOD SAMPLES}

Bovine dermis cells at $\pm 50 \%$ confluency growing in tubes containing the growth medium described above were infected with $0.5 \mathrm{~m} \ell$ heparinized blood. After $24 \mathrm{~h}$ the medium was removed and the cells were washed twice with phosphate buffered saline containing $\mathrm{Mg}^{2+}$ and $\mathrm{Ca}^{2+}$ (PBS+) and gentamycin $(0.05 \mathrm{mg} / \mathrm{m} \ell)$. The medium was replaced with MEM containing $5 \%$ foetal calf serum, L-glutamine, $0.2 \%$ sodium bicarbonate and gentamycin $(0.05 \mathrm{mg} / \mathrm{m} \ell)$. The cell cultures were observed daily for CPE. After 14 days negative cultures were frozen briefly at $-70{ }^{\circ} \mathrm{C}$ and thawed. A second passage was done and observed for 14 days. Isolates were stored at $-70^{\circ} \mathrm{C}$.

\section{SKIN BIOPSIES}

For virus isolation, biopsy tissue was minced using sterile scissors and forceps and then using sterile techniques ground with a pestle in a mortar containing sterile sand. Ten millilitres PBS+ containing gentamycin $(0.1 \mathrm{mg} / \mathrm{m} \ell)$, ampicillin $(0.05 \mathrm{mg} / \mathrm{m} \ell)$ (Intramed Ampicillin Inj. $500 \mathrm{mg}$ ) and amphotericin B $(5 \mu \mathrm{g} / \mathrm{m} \ell)$ (inj. Fungizone, Bristol-Myers Squibb) were added. The suspension was left to stand overnight at $4^{\circ} \mathrm{C}$. The samples were partially clarified by centrifugation at $2000 \mathrm{rpm}$ for 3-5 min to remove gross particles and $0.5 \mathrm{~m} \ell$ of supernatant was used to inoculate monolayers of bovine dermis cells growing in the medium described above. Cultures were observed daily for 14 days for CPE.

The growth medium was replaced if it appeared cloudy due to bacterial or fungal contamination. After 14 days negative cell cultures were blind-passaged onto a fresh cell culture monolayer and observed for another 14 days or until typical CPE changes occurred.

A negative control for virus isolation consisted of a cell monolayer without any virus and a positive control consisted of a cell monolayer inoculated with 0.2-0.5 m $\ell$ LSD virus ( $V$ 248/93) suspension at a titre of $4 \log \mathrm{TCID}_{50}$.

\section{Polymerase chain reaction}

The extraction method used was a modification of the method described by Schwartz, Varde, Nadelman, Wormsel \& Fish (1997) and Gubbels, De Vos, Van der Weide, Viseras, Schouls, De Vries \& Jongejan (1999). A volume of $200 \mu \ell$ blood in EDTA frozen at $-70^{\circ} \mathrm{C}$ was thawed. The samples were suspended in $100 \mu \ell$ lysis buffer containing $0.378 \mathrm{~g} \mathrm{KCl}$, $1 \mathrm{~m} \ell$ Tris (1.0 M, pH 8), $0.5 \mathrm{~m} \ell$ Tween 20 and $60 \%$ guanidine thiocyanate (Roche Diagnostics) in $100 \mathrm{~m} \ell$. Protein bands were digested by adding $1 \mu \ell$ of Proteinase K $(10 \mathrm{mg} / \mathrm{m} \ell)$ (Invitrogen, Laboratory Specialist Services Ltd) to each sample. The portions of the skin biopsies to be used in this test were first cut into fine pieces using sterile scissors and forceps and ground with a pestle in a mortar. The samples were suspended in $1 \mathrm{~m} \ell$ lysis buffer containing $60 \%$ guanidine. A volume of $10 \mu \ell$ Proteinase $\mathrm{K}(10 \mathrm{mg} / \mathrm{m} \ell)$ was added. All the samples were incubated at $56^{\circ} \mathrm{C}$ overnight and then heated for 10 $\min$ at $100^{\circ} \mathrm{C}$ to denature the enzyme.

A Phenol:Chloroform:Isoamylalcohol (25:24:1, v/v, Invitrogen) solution was added to each sample at a $1: 1$ volume and the samples were mixed while incubating at room temperature for $10 \mathrm{~min}$. After cen- 
trifugation (13 $000 \mathrm{rpm}$ for $15 \mathrm{~min}$ ) the upper, aqueous phase was collected and DNA was precipitated using ice cold, $100 \%$ ethanol. After centrifugation (13 $000 \mathrm{rpm}$ for $15 \mathrm{~min}$ ) pellets were washed with $70-75 \%$ ethanol and centrifuged again at 13000 rpm for $1 \mathrm{~min}$. Pellets were dried thoroughly and resuspended in $30 \mu \ell$ of distilled water.

The PCR primers were developed from the viral attachment protein encoding gene and have the following sequences (Ireland \& Binepal 1998):

Forward primer 5'-d TTTCCTGATTTTTCTTACTAT3'

Reverse primer 5'-d AAATTATATACGTAAATAAC 3

The size of the amplicon was 192 bp (Ireland \& Binepal 1998).

A Platinium $\AA$ Quantitative PCR SuperMix-UDG (2X) reaction mixture (Invitrogen, Life Technologies) was used for amplification of nucleic acid templates. DNA amplification was carried out in a final volume of $25 \mu \ell$ containing $12.5 \mu \ell$ Platinium ${ }^{\circledR}$ Quantitative PCR SuperMix-UDG, $1 \mu \ell 0.20 \mathrm{mM}$ each primer, $9.5 \mu \ell$ distilled water and $1 \mu \ell$ DNA sample.

The reaction was carried out in a Perklin-Elmer Gen Amp 9600 PCR system. To remove any urasil residues from the PCR mixture the PCR started with one cycle of $42^{\circ} \mathrm{C}$ for $2 \mathrm{~min}$ and $94^{\circ} \mathrm{C}$ for $10 \mathrm{~min}$. The initial cycle was $94^{\circ} \mathrm{C}$ for $1 \mathrm{~min}, 50^{\circ} \mathrm{C}$ for $30 \mathrm{~s}$ and $72^{\circ} \mathrm{C}$ for $1 \mathrm{~min}$. This was followed by 40 cycles of $94^{\circ} \mathrm{C}$ for $1 \mathrm{~min}, 50^{\circ} \mathrm{C}$ for $30 \mathrm{~s}$, and $72^{\circ} \mathrm{C}$ for $1 \mathrm{~min}$, and a final elongation step of $72^{\circ} \mathrm{C}$ for $1 \mathrm{~min}$ to complete the extension of the primers (Ireland \& Binepal 1998).

A water control and previously tested positive and negative control samples were always included when blood and skin specimens were tested using the PCR. Amplified products were analysed using a 100 bp DNA ladder (Whitehead Scientific Ltd) as a molecular marker on $1.5 \%$ agarose gels. Gels were stained using ethidium bromide $(1 \mu \mathrm{g} / \mathrm{m} \ell)$ in Tris EDTA (TE) and amplicons were visualized using an UV transilluminator at a wave length of $590 \mathrm{~nm}$. Positive reactions were confirmed according to size.

\section{Transmission electron microscopy}

The preparation and negative staining of skin specimens for TEM were made according to the SOPs of the Electron Microscopy Unit. Samples were ground in a mortar with a pestle and a small volume of distilled water was added. Aqueous material was centrifuged for $15 \mathrm{~min}$ at $5000 \mathrm{rpm}$. The supernatant was collected and centrifuged again for 45 $\mathrm{min}$ at $13000 \mathrm{rpm}$. Each pellet was rinsed carefully with distilled water and diluted with one droplet of water. Pellets were stained with $3 \%$ phosphotungstic acid (PTA). Grids were examined using a Philips CM 10 transmission electron microscope in the Electron Microscopy Unit.

\section{RESULTS}

\section{Clinical signs}

Before the onset of the experiment all the bulls were healthy, eating well and had apparently adapted to their new environment. Bulls 1 and 2 were the smallest but were in good condition. Bulls 3 and 4 were in good physical condition with shiny hair coats. Bulls 7 and 8 were very thin.

The animals were divided into three groups according to the severity of the clinical signs after inoculation as shown in Table 1. Two of them developed severe, generalized disease (Group 1), two manifested mild disease with fever and a few skin lesions on the neck and back (Group 2), and two had only transient fever but no other signs (Group 3).

In this study the day of inoculation was counted as Day 1 p.i. An increase in rectal temperature, which lasted for 3-14 days, was recorded in all animals from Days 5 and 6 p.i. (Fig. 1).

Group 1: In Bulls 1 and 2 the fever persisted for 10-14 days; in Bull 1, at the height of the reaction, it exceeded $41^{\circ} \mathrm{C}\left(41.5^{\circ} \mathrm{C}\right)$ for 3 days (Fig. 1). After the main fever reaction Bull 1 had a rise in temper-

TABLE 1 Grouping of animals according to the severity of clinical signs

\begin{tabular}{|l|l|l|l|l|l|}
\hline Group no. & Clinical signs & Animal no. & Age (months) & Mass $(\mathrm{kg})$ & Breed \\
\hline 1 & Severe & 1 & 11 & 232 & Dexter \\
& & 2 & 15 & 250 & Dexter \\
2 & Mild & 7 & 17 & 236 & Friesian \\
& & 8 & 20 & 310 & Friesian \\
3 & Inapparent & 3 & 16 & 295 & Dexter cross \\
& & 4 & 14 & 321 & Dexter cross \\
\hline
\end{tabular}


ature $\left(39.2^{\circ} \mathrm{C}\right)$ for 1 day on Day 22 p.i. Bull 2 also had a rise in temperature $\left(39.4^{\circ} \mathrm{C}\right)$ on Day 24 p.i. Both animals developed ulcerative lesions on the muzzle and nostrils and numerous skin nodules over the entire body. In addition, they showed salivation, lachrymation, a mucopurulent nasal discharge and a slight enlargement of their superficial lymph nodes. Bull 1 had subcutaneous oedema between the tarsal joint and fetlock of the right hind leg. Because of respiratory distress, high fever and inappetence Bull 1 was treated with $12 \mathrm{~m} \ell$ of sulfatrimetoprim (Sulfatrim $240 \AA$, Phenix, Virbac) per day administrated either IV or IM for 10 days and $4 \mathrm{~m} \ell$ of phenylbutazone (Phenylarthrite $\AA$, $200 \mathrm{mg} / \mathrm{m} \ell$, Centaur, Bayer) every second day, IV. These treatments were started on Day 10 p.i.

Group 2: Bulls 7 and 8 had elevated rectal temperatures for $5-7$ days which did not exceed $40.5^{\circ} \mathrm{C}$. A few skin lesions developed mainly on the neck, back and perineal area of both animals but they showed no other clinical signs. Both animals developed a ringworm infection 30-34 days p.i.

Group 3: In Bulls 3 and 4, the fever lasted 3-6 days and only on 1 day did it exceed $40^{\circ} \mathrm{C}$ in Bull 4. A slight rise $\left(39.3^{\circ} \mathrm{C}\right)$ in rectal temperature was recorded for Bull 3 on Day 18 p.i. No other clinical signs were observed in either of the animals.

\section{Virus isolation}

\section{Heparinized blood samples}

Group 1: Virus was isolated from Bull 1 for 11 days from Days 6-16 p.i. Fever commenced on Day 5 p.i. and virus was isolated from the blood sample collected on the following day (Day 6 p.i.). The rectal temperature of Bull 2 started to rise on Day 6 p.i. and virus was isolated from its blood for 11 days between Days 6 and 16 p.i.

Group 2: Virus was isolated from Bull 7 only once (on Day 16 p.i.), 10 days after the fever had commenced (on Day 6 p.i.). From Bull 8 virus was isolated four times between Days 5 and 16 p.i. (on Days 5, 8, 10 and 16 p.i.), which was 1 day before the rectal temperature started to rise (on Day 6 p.i.).

Group 3: From Bull 3 virus was isolated three times between Days 11 and 16 (on Days 11, 12 and 16 p.i.). This was 5 days after the onset of fever (on Day 6 p.i.). From Bull 4 virus was isolated seven times between Day 5 (i.e. on the same day that the fever commenced) and Day 16 p.i. (on Days 5, 6, 9, $10,12,14$ and 16 p.i.).

\section{Skin biopsies}

Group 1: Virus was isolated from Bull 1 on Day 10

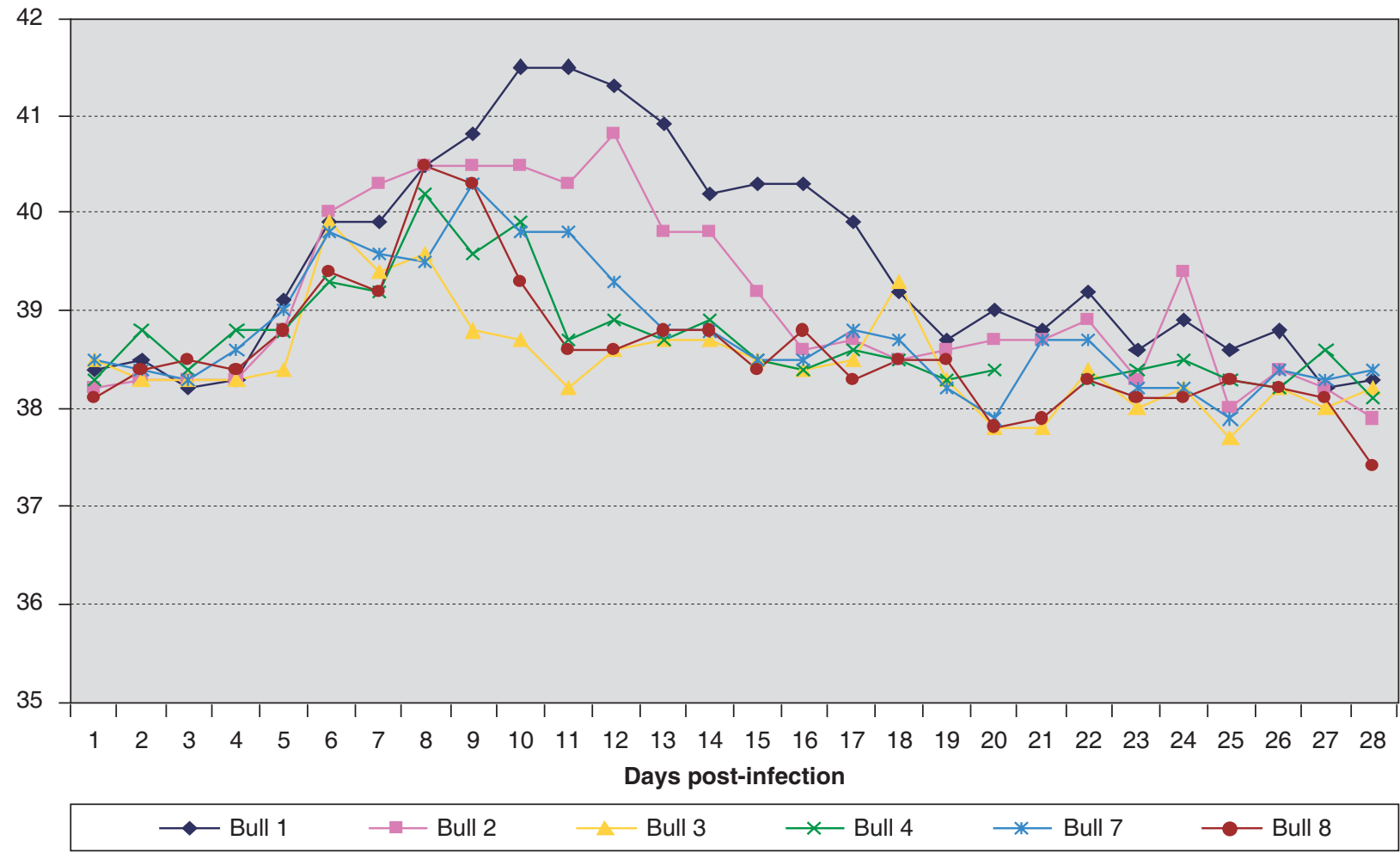

FIG. 1 Temperature reaction in the bulls 


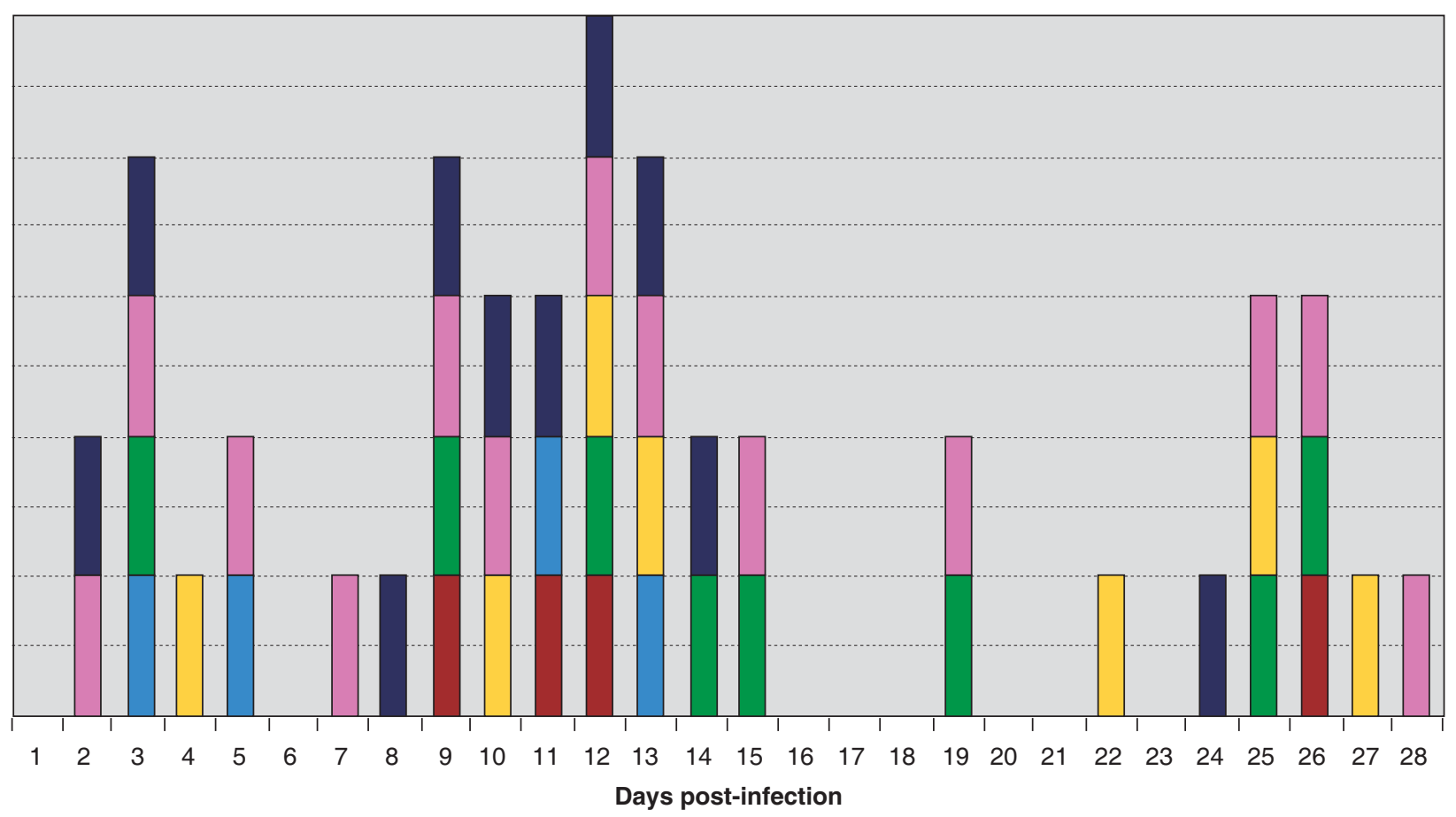

口 Bull 1

$\square$ Bull 2

$\square$ Bull 3

$\square$ Bull 4

$\square$ Bull 7

$\square$ Bull 8

FIG. 2 Virus isolations on bovine dermis cell cultures from blood samples collected in heparin

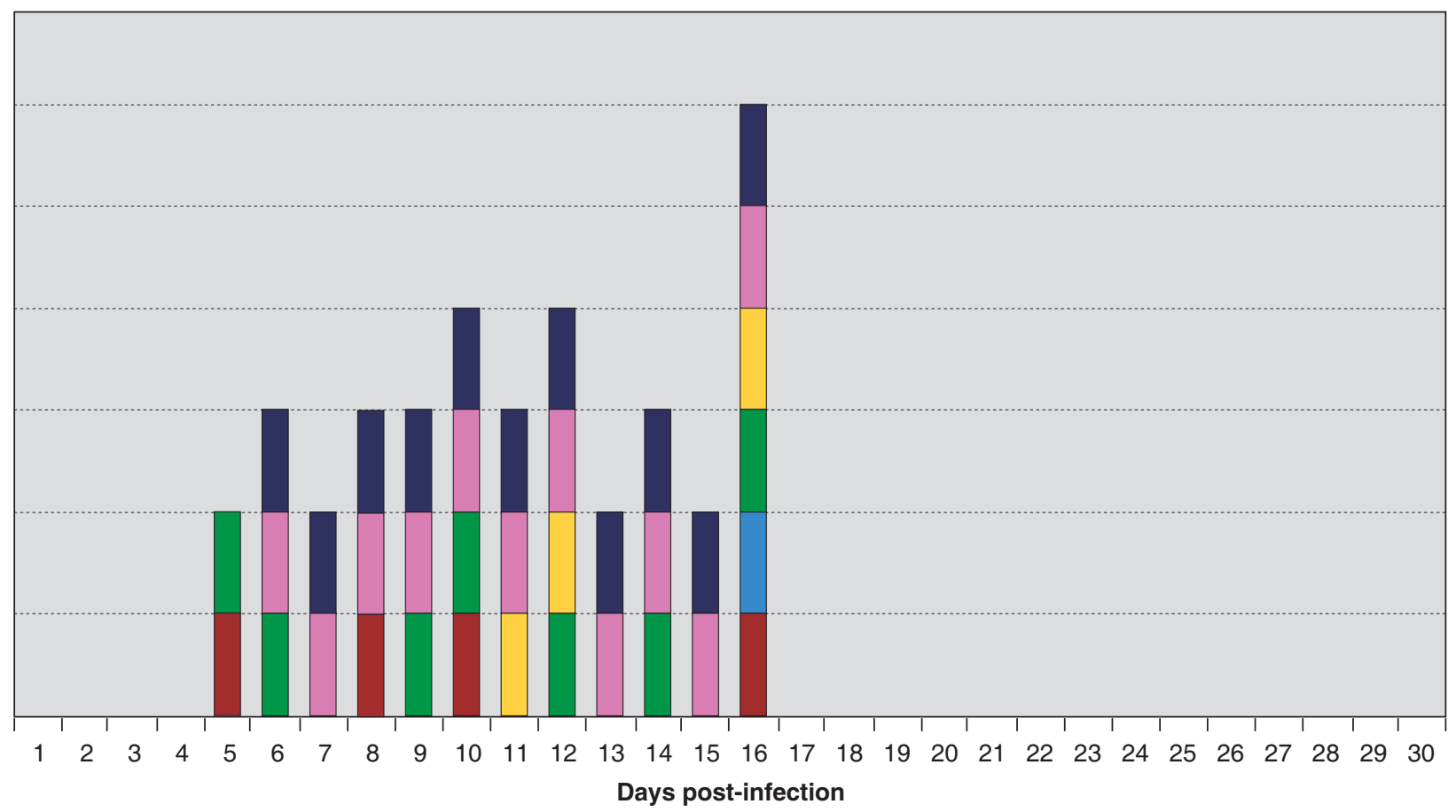

\section{Bull 1}

$\square$ Bull 2

$\square$ Bull 3

$\square$ Bull 4

$\square$ Bull 7

$\square$ Bull 8

FIG. 3 PCR results from EDTA blood samples 
p.i. when the first skin sample was collected and for the last time on Day 39 p.i. From Bull 2 virus was isolated once, 26 days after the first skin lesions appeared on Day 33 p.i.

Group 2: No virus was isolated from skin biopsies collected from Bull 7. From a skin lesion of Bull 8 virus was isolated on Day 10 p.i.

Group 3: The bulls of this group did not develop any skin lesions.

\section{Polymerase chain reaction}

\section{EDTA blood samples}

Group 1: Both Bulls 1 and 2 gave positive PCR results on Days 2 and 3 p.i. Bull 1 was positive seven times between Days 8 and 14 p.i. (on Days 8-14). On Day 24 p.i. it became positive again but only for 1 day. Bull 2 gave positive PCR results seven times between Days 5 and 15 p.i. (on Days $5,7,9,10,12,13$ and 15). After the main viraemic period Bull 2 showed positive PCR results again on Days 19, 25, 26 and 28 p.i.

Group 2: Bull 7 gave one positive PCR result on Day 3 p.i. It had PCR positive samples on Days 5, 11 and 13 p.i. after which it remained negative. Bull 8 registered positive results on Days 9,11 and 12 p.i. and one positive result on Day 26 p.i.

Group 3: Bull 3 gave its first positive PCR result on Day 4 p.i. Between Days 10 and 13 p.i. it was PCR positive three times on Days 10, 12 and 13 p.i. After 8 negative days it became positive again on Days 22, 25 and 27 p.i. Bull 4 gave its first positive PCR result on Day 3 p.i. Between Days 9 and 15 p.i. it gave four positive results on Days 9, 12, 14 and 15 p.i. subsequently on Days 19,25 and 26 p.i. it was PCR positive again.

\section{Skin biopsies}

Group 1: The first skin lesions appeared in Bull 1 on Day 6 p.i. and in Bull 2 on Day 7 p.i. The PCR failed to detect viral DNA from the skin biopsy of Bull 1 collected on Day 10 p.i. even though LSD virus was isolated in cell culture and it was demonstrated using TEM. From Bull 1, 17 samples were collected, mainly skin biopsies, but also several scabs. The first PCR-positive skin nodule was collected on Day 18 p.i. and the skin biopsies of this bull remained positive until Day 92 p.i. However, biopsies collected from this animal on Days 25, 47, 75 and 81 p.i. were all negative.
The first two skin samples collected on Days 11 and 18 p.i. from Bull 2 were negative, but positive PCR results were obtained in bioposies taken on Day 25 p.i. and, apart from the one collected on Day 81 p.i., it remained positive until Day 85 p.i.

Group 2: Bulls 7 and 8 developed very few skin lesions. These occurred mainly in the area of the neck and back but a small number were present in the perineal area. The first lesions in Bull 7 developed on Day 10 p.i. and skin biopsies from it were PCR-positive on Days 12 and 25 p.i. The skin biopsy collected on Day 18 p.i. was PCR negative. No skin lesions were observed in this animal after Day 25 p.i. Skin lesions appeared in Bull 8 on Day 8 p.i. The PCR demonstrated viral DNA from skin biopsies only 2 days after the appearance of the first skin lesion on Day 10 p.i. This animal remained positive until Day 18 p.i. The last skin biopsy collected on Day 25 p.i. was negative.

Group 3: These bulls did not develop skin lesions.

\section{Transmission electron microscopy}

The results of the TEM examinations are given in Table 2.

Group 1: Lumpy skin disease virus was detected in the first skin biopsy collected on Day 10 p.i. from Bull 1, which was 4 days after the first appearance of skin lesions. In biopsies collected on Days 18 and 25 p.i. the presence of LSD virus was suspected but not confirmed. Virus was again detected from a specimen collected on Day 33 p.i. No virus was detected in ten biopsy specimens collected from Bull 1 between Days 39 and 106 p.i. or from the skin specimens of Bull 2 collected between Days 11 and 106 p.i. Virus was detected in a skin nodule of Bull 2 collected on Day 33 p.i.

Group 2: Bull 7 did not have any positive samples. In Bull 8 virus was detected on Day 25 p.i.

\section{DISCUSSION}

The effective control or eradication of LSD in endemic and non-endemic areas requires rapid and accurate diagnostic methods to confirm a presumptive diagnosis. Recent research has focused mainly on transmission of the disease (Kitching \& Taylor 1985; Kitching \& Mellor 1986; Carn \& Kitching 1995a; Chihota, Rennie, Kitching \& Mellor 2001) and development of recombinant vaccines (Ngichabe, Wamwayi, Barrett, Ndungu, Black \& Bostock 1997; Aspden, Van Dijk, Bingham, Cox, Passmore 
TABLE 2 Transmission electron microscopy results of the skin biopsies of the bulls

\begin{tabular}{|l|l|l|l|l|}
\hline Day p.i. & Bull 1 & Bull 2 & Bull 7 & Bull 8 \\
\hline 10 & Pos & ND & ND & Neg \\
11 & ND & Neg & ND & ND \\
12 & ND & ND & Neg & ND \\
18 & Suspect & Neg & Neg & Neg \\
25 & Suspect & Neg & Neg & Suspect \\
33 & Pos & Suspect & ND & ND \\
39 & Neg & Neg & ND & ND \\
47 & Neg & Neg & ND & ND \\
54 & Neg & ND & ND & ND \\
60 & Neg & ND & ND & ND \\
67 & Neg & ND & ND & ND \\
75 & Neg & ND & ND & ND \\
81 & Neg & ND & ND & ND \\
92 & Neg & ND & ND & ND \\
99 & Neg & Neg & ND & ND \\
106 & Neg & Neg & ND & ND \\
113 & Neg & ND & ND & ND \\
\hline
\end{tabular}

ND $=$ Not done

TABLE 3 Temperature reaction relative to the development of skin lesions

\begin{tabular}{|l|l|l|l|l|c|}
\hline Group no. & Animal no. & $\begin{array}{l}\text { Onset of fever } \\
\text { (day p.i.) }\end{array}$ & $\begin{array}{l}\text { Duration of } \\
\text { fever (days) }\end{array}$ & $\begin{array}{l}\text { Average duration of } \\
\text { fever (days) }\end{array}$ & $\begin{array}{l}\text { Appearance of skin } \\
\text { lesions (day p.i.) }\end{array}$ \\
\hline 1 & 1 & 5 & 14 & 12 & 6 \\
2 & 2 & 6 & 10 & & 7 \\
& 7 & 6 & 7 & 6 & 10 \\
& 8 & 6 & 5 & 4.5 & 8 \\
& 3 & 6 & 3 & & No skin lesions \\
& 4 & 5 & 6 & Nkin lesions \\
\hline
\end{tabular}

\& Williamson 2002; Ngichabe, Wamwayi, Ndungu, Mirangi, Bostock, Black \& Barret 2002). No data on comparative studies of different diagnostic methods of LSD have been published. The use of the PCR for the detection of LSD virus nucleic acid from skin biopsies and tissue culture supernatant has been published (Ireland \& Binepal 1998; Markoulatos, Mangana-Vougiouka, Koptopoulos, Nomikou \& Papadopoulos 2000) but no studies have been undertaken on the persistence of the virus in blood and skin using the PCR.

In the study described here, a virulent South African field isolate of LSD virus was used to infect the six bulls. The intravenous route of infection was selected because previous data indicate this route to be the most effective way to produce severe generalized disease in experimentally infected cattle (Carn \& Kitching 1995a).

The incubation period of 4-5 days recorded in the bulls in this study is in agreement with that reported in earlier publications, in which the incubation period after experimental infection was 4-14 days (Haig 1957; Capstick 1959; Prozesky \& Barnard 1982; Carn \& Kitching 1995b). All the bulls became infected and developed fever and viraemia. However, the severity of clinical manifestations varied in the bulls (Table 1). This correlates well with earlier observations that less than half of the cattle infected experimentally with LSD virus or naturally exposed during an outbreak will develop generalized disease (Weiss 1968; Prozesky \& Barnard 1982; Carn \& Kitching 1995b). In our study two bulls developed severe disease, two bulls showed mild disease and two bulls showed no clinical disease apart from fever (Table 1). The fever reaction correlated well with the development of clinical signs. Fever persisted for the longest period (12 days on average) in animals of Group 1 that showed the most severe disease (Table 3 ). The mean duration of fever in mildly affected animals (Group 2) was 6 days. The two animals that did not develop clinical signs (Group 3) had the shortest febrile reaction (4.5 days on average). No clear 
biphasic fever response as has been reported in previous publications was detected (Barnard, Munz, Dumbell \& Prozesky 1994).

Bulls 1, 2 and 8 developed skin lesions 1-2 days after the onset of fever. Bull 7 developed skin lesions 4 days after the rectal temperature started to rise. This finding correlates well with the observation that skin lesions appear within $48 \mathrm{~h}$ of the first rise in temperature (Weiss 1968) or within 4-7 days of subcutaneous inoculation of the virus (Prozesky \& Barnard 1982).

In this experiment bovine dermis cells (BDC) were chosen to be used in virus isolation because they are susceptible to LSD virus infection and show typical CPE. Although BDC are primary cells, they live long enough to ensure the isolation of the virus. In the present study the appearance of CPE took sometimes only 4 days to develop but it usually became apparent between the $7^{\text {th }}$ to the $10^{\text {th }}$ day. On one occasion it took as long as 12 days to develop. Negative cell cultures were blind-passaged once and sometimes twice to ensure that the results were negative.

The severity of the clinical signs did not correlate with the length of viraemia in the infected bulls. Virus was isolated for the longest period of time (12 days) from the blood of Bull 4, which developed no clinical signs, and Bull 8, which was only mildly affected. However, the viraemic period in these two bulls was only one day longer than that of Bulls 1 and 2 that both showed severe disease (11 days). The mean length of viraemia detected by virus isolation in the animals of Groups 2 and 3 was 6.5 and 9 days, respectively (Table 4). The viraemia in the bulls that developed no clinical sings persisted for a longer period on average than that in the bulls that showed mild disease.

No virus could be isolated from the blood samples of the bulls after Day 16 p.i., which is similar to the observations of Carn \& Kitching (1995b). The bulls remained viraemic for a longer period than has previously been determined. Weiss (1968) demonstrated virus in the blood of experimentally infected cattle for a period of 4 days following the appearance of fever and generalized skin lesions. In a more recent study LSD virus was isolated in cultures of lamb testis cells from blood samples of experimentally infected cattle for a period of 9 days, from the $3^{\text {rd }}$ to the $11^{\text {th }}$ day p.i. (Carn \& Kitching 1995b). In the present study LSD virus was isolated from the blood of all the bulls for 1-12 days between Days 5 and 16 p.i. When seven cattle were infected with LSD virus using the intradermal and subcutaneous routes at multiple sites on the side of the neck, viraemia was detected in only two of the animals using virus isolation techniques (Prozesky \& Barnard 1982). The total volume of the virus suspension used in their study to infect each animal was $2 \mathrm{~m} \ell$ and the titres varied between 4.5 and $6.0 \log \mathrm{TCID}_{50}$.

In an experiment to determine the effect of the infecting dose and the route of infection, Carn \& Kitching (1995b) used different titres of a virus suspension (2-6.5 log $\mathrm{TCID}_{50}$ ) to infect cattle by placing LSD virus on the conjunctiva or using the intranasal, intradermal and intravenous routes. Eleven out of 25 animals infected intradermally developed only a local reaction at the inoculation site and a viraemia was detected in two of them. Only five of all the 40 infected animals showed both severe generalized disease and a viraemia, which persisted for up to 9 days. Of these five animals, three were infected via the intravenous route, one intranasally and one via the intradermal route.

In the present study virus was isolated from blood samples of four of the bulls collected 1 day before (Bull 8), the same day (Bulls 2 and 4) or 1 day after (Bull 1) the onset of fever. However, from Bull 7, that showed mild disease, virus was isolated only 10 days after the onset of fever and from Bull 3 that did not develop clinical signs apart from the fever, virus was isolated 5 days after its onset.

Depending on how rapidly the confirmation of the presumptive diagnosis is required, the virus isolation technique may be too time-consuming because members of the genus Capripoxvirus grow very slowly in cell cultures and the development of CPE may take up to 14 days on primary isolation (Alexander, Plowright \& Haig 1957). Several passages may also be required before the virus becomes adapted and will grow on cells. The results of this study indicate that in animals showing mild or inapparent disease it took 5-10 days after the onset of the febrile reaction before LSD virus could be isolated from blood samples (Table 4), which will delay the confirmation of the diagnosis for even longer.

A tentative diagnosis of LSD is usually based on clinical signs. The disease in animals that develop only a few skin lesions and/or transient fever may therefore be difficult to diagnose and may be confused with pseudo-lumpy skin disease (Barnard et al. 1994). The present study indicates that virus isolation on BDC cultures is a useful method but it may be too time-consuming to be used as a first diag- 
nostic method. It is nevertheless a valuable tool to detect the viability of the virus but should be used in combination with other tests.

There are no published reports on the persistence of LSD virus in the blood of experimentally infected cattle using the PCR. In this study five of the bulls (1-4 and 7) were found to be PCR-positive on Days 2-4 p.i. (Fig. 3), the virus in the blood probably being the virus that was inoculated. The blood samples of all the animals were negative on Day 6 p.i. The blood samples of all the experimental animals became PCR positive within 4 days after the onset of fever (mean 2 days) and skin lesions appeared approximately 1-4 days (mean 2 days) after the onset of the fever reaction (Table 4). The results of this experiment indicate that the PCR was able to detect the nucleic acid of the LSD virus from the blood samples of the experimental bulls on the same day that the skin nodules appeared.

The blood of Bull 2 remained PCR positive for the longest period ( 11 days). The mean duration of the viraemic period in all the bulls determined using the PCR was 7 days and it was 8.8 days using virus isolation. The PCR could detect virus in the blood of animals that showed severe, mild or inapparent disease. The blood samples of all the animals were PCR negative after Day 15 p.i., which correlates well with the virus isolation results (in which virus was isolated up to Day 16 p.i.) (Table 4).

The blood samples of all the bulls except Bull 7 were PCR positive for 1-4 days between Days 19 and 28 p.i. As discussed above Bulls 1-3 showed slightly elevated rectal temperatures between Days 18 and 24. No virus could be isolated during this period from the blood samples of any of the bulls. During this time Bulls 1 and 2 developed severe skin lesions over their entire bodies. Bulls 7 and 8 showed very few lesions, but none were detected in Bulls 3 and 4 . Virus was isolated from skin biopsies of Bull 1 between Days 10 and 39 p.i. and from those of Bull 2 only on Day 33 p.i. This finding indicates that the skin lesions contained viable virus between Days 19 and 28 p.i.

This study has revealed the PCR to be a fast and sensitive diagnostic technique to detect LSD virus nucleic acid in blood samples.

The reason why LSD virus could not be isolated from the skin biopsies collected from Bull 7, and why it was isolated only once from those collected from Bulls 2 and 8 , is not clear. The concentration of the virus in the skin lesions may have been too low, the size of the sample may have been too small or a failure in the techniques used in processing the samples may have occurred.

TABLE 4 The temperature reaction and the appearance of skin lesions relative to virus isolation and PCR results of blood samples. The numbers in brackets indicate the number of positive test results during the time period

\begin{tabular}{|c|c|c|c|c|c|c|c|}
\hline Group no. & Animal no. & $\begin{array}{l}\text { Onset of } \\
\text { fever } \\
\text { (day p.i.) }\end{array}$ & $\begin{array}{l}\text { Appearance of } \\
\text { skin lesions } \\
\text { (day p.i.) }\end{array}$ & $\begin{array}{l}\text { Positive virus } \\
\text { isolation } \\
\text { (days p.i.) }\end{array}$ & $\begin{array}{l}\text { Viraemic } \\
\text { period } \\
\text { (days) }\end{array}$ & $\begin{array}{l}\text { Positive } \\
\text { PCR } \\
\text { (days p.i.) }\end{array}$ & $\begin{array}{l}\text { Viraemic } \\
\text { period } \\
\text { (days) }\end{array}$ \\
\hline \multirow[t]{2}{*}{1} & 1 & 5 & 6 & $6-16(11 x)$ & 11 & $8-14(7 x)$ & 7 \\
\hline & 2 & 6 & 7 & $6-16(11 x)$ & 11 & $5-15(7 x)$ & 11 \\
\hline \multirow[t]{2}{*}{2} & 7 & 6 & 10 & $16(1 \mathrm{x})$ & 1 & $5-13(3 x)$ & 9 \\
\hline & 8 & 6 & 8 & $5-16(4 x)$ & 12 & $9-12(3 x)$ & 4 \\
\hline \multirow[t]{2}{*}{3} & 3 & 6 & No skin lesions & $11-16(3 x)$ & 6 & $10-13(3 x)$ & 4 \\
\hline & 4 & 5 & No skin lesions & $5-16(7 x)$ & 12 & $9-15(4 x)$ & 7 \\
\hline
\end{tabular}

TABLE 5 Detection of LSD virus / nucleic acid in skin lesions using TEM, VI and PCR

The numbers in brackets indicate the number of positive test results during the time period

\begin{tabular}{|c|c|c|c|c|c|}
\hline Group no. & Animal no. & $\begin{array}{l}\text { Appearance of } \\
\text { skin lesions } \\
\text { (day p.i.) }\end{array}$ & $\begin{array}{l}\text { Positive TEM results } \\
\text { (days p.i.) }\end{array}$ & $\begin{array}{l}\text { Positive virus } \\
\text { isolation } \\
\text { (days p.i.) }\end{array}$ & $\begin{array}{l}\text { Positive PCR } \\
\text { (days. p.i.) }\end{array}$ \\
\hline $\begin{array}{l}1 \\
2 \\
3\end{array}$ & $\begin{array}{l}1 \\
2 \\
7 \\
8 \\
3 \\
4\end{array}$ & $\begin{array}{l}6 \\
7 \\
10 \\
8 \\
\text { No skin lesions } \\
\text { No skin lesions }\end{array}$ & $\begin{array}{l}10-33(2 x) \\
\text { Suspected on Day } 33 \text { p.i. } \\
\text { None } \\
\text { Suspected on Day } 25 \text { p.i. }\end{array}$ & $\begin{array}{l}10-39(4 x) \\
33(1 x) \\
\text { None } \\
10(1 x)\end{array}$ & $\begin{array}{l}18-92(11 x) \\
25-85(8 x) \\
12-25(2 x) \\
10-18(2 x)\end{array}$ \\
\hline
\end{tabular}


Virus was isolated from the skin lesions of Bull 1 on Days 10, 18, 33 and 39 p.i. In this animal LSD virus remained viable for 33 days after the appearance of skin nodules. From Bull 2 virus was isolated once, on Day 33 p.i., which was 26 days after the appearance of the skin lesions. These results are in agreement with the earlier observation of Weiss (1968) that viable LSD virus particles remain for 33 days in the skin nodules after their first appearance.

Transmission electron microscopy demonstrated LSD virus in skin biopsies of Bull 1 between Days 10 and 33 p.i. This correlates well with the isolation of virus in cell cultures (Days 10-39 p.i.). This finding also corresponds with the observations of Davies, Krauss, Lund \& Taylor (1971) that virus could be detected by TEM in skin specimens collected between Days 9-21 p.i. Why the virus was detected in the skin biopsies of only one experimental animal is unclear. Incorrect procedures used in preparing the samples could be a reason or possibly more than one grid should have been prepared from each specimen as described by Davies et al. (1971). The size of the sample may also have been too small, which resulted in the virus concentration in the specimen being too low.

In Bulls 7 and 8 the PCR was able to detect LSD virus nucleic acid from the skin biopsies already 2 days after the appearance of skin nodules. However, it was not able to demonstrate LSD virus DNA from the first skin biopsy collected from Bull 1 on Day 10 p.i. even though the virus was isolated in cell culture and detected by TEM. The negative result may indicate a failure in the DNA extraction procedure or the presence of DNA amplificator inhibitors. In experiments done with sheep pox skin lesions, a dilution of skin biopsy samples at 1:10 was needed to remove DNA amplificatory inhibitors (Markoulatos et al. 2000).

The PCR could demonstrate viral DNA in the skin biopsies of Bull 1 (until Day 92 p.i.) and in Bull 2 (until Day 85 p.i.) for up to 3 months. The skin biopsies of Bull 7 remained positive until the last skin nodule was collected on Day 25 p.i. and Bull 8 until Day 18 p.i. No viral DNA was detected from biopsies collected from healthy-looking skin after all the skin lesions had disappeared. Since the PCR only detects nucleic acid, this result does not necessarily imply that LSD virus remains infective for such a long time in skin lesions.

These observations indicate that the PCR is a more sensitive test to detect LSD virus or viral nucleic acid in skin biopsies than virus isolation or TEM examination. The results of TEM, VI and PCR are compared in Table 5. In previous studies the PCR has been shown to have a greater sensitivity to detect capripoxviruses from skin biopsies than antigen trapping ELISA (Ireland \& Binepal 1998).

In conclusion, this study revealed that the PCR is a useful method for a rapid confirmation of the diagnosis of LSD. Virus isolation is still needed to detect the infectivity of the virus. The PCR could demonstrate LSD virus nucleic acid in blood and skin samples. Using both PCR and virus isolation techniques the persistence of the virus in blood and skin of experimentally infected animals was found to be for longer than had previously been shown. According to this study even though TEM is usually considered to be a fast and reliable method, a negative result should be confirmed by using another method.

\section{ACKNOWLEDGEMENTS}

We thank Prof. P.G. Howell for his valuable advice and constant support during this project, Prof. R.C. Tustin for his constructive editing of the article, Ms A-M. Bosman for assistance in molecular biology, Ms D. Nel and Ms A. Durand for assistance in virology and serology, and the personnel of the Department of Anatomy and Physiology, Electron Microscopy Unit for assistance in transmission electron microscopy examination of skin lesions.

The financial support received from the following institutes is greatly appreciated: Research and Science Foundation of Farmos, Finnish Veterinary Foundation, Department of Veterinary Tropical Diseases, Faculty of Veterinary Science, University of Pretoria, and Orion Pharma, Finland for donating of Domosedan sedative for the project.

\section{REFERENCES}

ALEXANDER, R.A., PLOWRIGHT, W. \& HAIG, D.A. 1957. Cytopathogenic agents associated with lumpy skin disease of cattle. Bulletin of Epizootic Diseases of Africa, 5:489-492.

ASPDEN, K., VAN DIJK, A.A., BINGHAM, J., COX, D., PASSMORE, J.A. \& WILLIAMSON, A.L. 2002. Immunogenicity of a recombinant lumpy skin disease virus (Neethling vaccine strain) expressing the rabies virus glycoprotein on cattle. Vaccine, 20:2693-2701.

BARNARD, B.H.J., MUNZ, E., DUMBELL, K. \& PROZESKY, L. 1994. Lumpy skin disease, in Infectious diseases of livestock with special reference to Southern Africa, edited by J.A.W. Coetzer, G.R. Thomson \& R.C. Tustin. Cape Town: Oxford University Press Southern Africa.

CAPSTICK, P.B. 1959. Lumpy skin disease-experimental infection. Bulletin of Epizootic Diseases of Africa, 7:51-62. 
CARN, V.M. 1993. Control of capripox virus infections. Vaccine, $11: 1275-1579$

CARN, V.M. 1995. An antigen trapping ELISA for the detection of capripoxvirus in tissue culture supernatant and biopsy samples. Journal of Virological Methods, 51:95-102.

CARN, V.M. \& KITCHING, R.P. 1995a. An investigation of possible routes of transmission of lumpy skin disease virus (Neethling). Epidemiology and Infection, 114:219-226.

CARN, V.M. \& KITCHING, R.P. 1995b. The clinical response of cattle experimentally infected with lumpy skin disease (Neethling) virus. Archives of Virology, 140:503-513.

CARN, V.M., KITCHING, R.P., HAMMOND, J.M. \& CHAND, P. 1994. Use of a recombinant antigen in an indirect ELISA for detecting bovine antibody to capripoxvirus. Journal of Virological Methods, 49:285-294.

CHIHOTA, C.M., RENNIE, L.F., KITCHING, R.P. \& MELLOR, P.S. 2001. Mechanical transmission of lumpy skin disease virus by Aedes aegypti (Diptera: Culicidae). Epidemiology and Infection, 126:317-321.

DAVIES, F.G. 1991. Lumpy skin disease of cattle: a growing problem in Africa and the Near East. World Animal Review, 68(3):37-42.

DAVIES, F.G., KRAUSS, H., LUND, J. \& TAYLOR, M. (1971). The laboratory diagnosis of lumpy skin disease. Research in Veterinary Science, 12:23-127.

GUBBELS, J.M., DE VOS, A.P., VAN DER WEIDE, M., VISERAS, J., SCHOULS, L.M., DE VRIES, E. \& JONGEJAN, F. 1999. Simultaneous detection of bovine Theileria and Babesia species by reverse line blot hybridisation. Journal of Clinical Microbiology, 37(6):1782-1789.

HAIG, D.A. 1957. Lumpy skin disease. Bulletin of Epizootic Diseases of Africa, 5:421-430.

HEINE, H.G., STEVENS, M.P., FOORD, A.J. \& BOYLE, D.B. 1999. A capripoxvirus detection PCR and antibody ELISA based on the major antigen P32, homologue of the vaccinia virus H3L gene. Journal of Immunological Methods, 227: 187-196.
IRELAND, D.C. \& BINEPAL, Y.S. 1998. Improved detection of capripoxvirus in biopsy samples by PCR. Journal of Virological Methods, 74:1-7.

KITCHING, R.P. \& MELLOR, P.S. 1986. Insect transmission of capripoxvirus. Research in Veterinary Science, 40:255-258.

KITCHING, R.P. \& TAYLOR, W.P. 1985. Transmission of capripoxviruses. Research in Veterinary Science, 39:196- 199.

MARKOULATOS, P., MANGANA-VOUGIOUKA, O., KOPTOPOULOS, G., NOMIKOU, K. \& PAPADOPOULOS, O. 2000. Detection of sheep poxvirus in skin samples by a multiplex polymerase chain reaction. Journal of Virological Methods, 84:161-167.

NGICHABE, C.K., WAMWAYI, H.M., BARRETT, T., NDUNGU, E.K., BLACK, D.N. \& BOSTOCK, C.J. 1997. Trial of capripoxvirus-rinderpest recombinant vaccine in African cattle. Epidemiology and Infection, 118:63-70.

NGICHABE, C.K., WAMWAYI, H.M., NDUNGU, E.K., MIRANGI, P.K., BOSTOCK, C.J., BLACK, D.N. \& BARRET, T. 2002. Long term immunity in African cattle vaccinated with recombinant capripox-rinderpest virus vaccine. Epidemiology and Infection, 128:343-349.

OIE's computer datapage, Handistatus II. Multiannual animal disease status. http://www.oie.int/hs2/report.asp?lang=en

PROZESKY, L. \& BARNARD, B.J.H. 1982. A study of the pathology of lumpy skin disease in cattle. Onderstepoort Journal of Veterinary Research, 49:167-175.

REED, L.J. \& MUENCH, H. 1938. A simple method of estimating fifty per cent endpoints. American Journal of Hygiene, 27: 493-497.

SCHWARTZ, I., VARDE, S., NADELMAN, R.B., WORMSEL, P. \& FISH, D. 1997. Inhibition of efficient polymerase chain reaction amplification of Borrelia burgdorferi DNA in bloodfed ticks. American Journal of Tropical Medicine and Hygiene, 56:339-342.

THOMAS, A.D. \& MARÉ, C. v. E. 1945. Knopvelsiekte. Journal of South African Veterinary Medical Association, 16:36-43.

WEISS, K.E. 1968. Lumpy skin disease virus. Virology Monographs, 3:111-131. 